\title{
Involving University Students in Intercultural Communicative Competence Activities through the Use of Cultural Products and Practices ${ }^{1}$
}

\section{Involucrando estudiantes universitarios en actividades de competencia comunicativa intercultural a través de productos y prácticas culturales}

\author{
Milton Gerardo Hernández García ${ }^{2}$ \\ milton7@yahoo.es \\ Universidad Pedagógica y Tecnológica de Colombia, Tunja, Colombia
}

Received: August 3, 2015

Accepted: November 5, 2015

How to cite this article (APA, 6th ed.): Hernández, M. (2016). Involving elementary level students in intercultural communicative competence activities through the use of cultural products and practices. Enletawa Journal, 9 (1), 13-32

\footnotetext{
Abstract

This document presents the findings of a research study developed with elementary level of English students from Instituto Internacional de Idiomas at Universidad Pedagógica y Tecnológica de Colombia. A series of pedagogical interventions were designed, in response to an initial diagnostic, which explored students' Intercultural Communicative Competence (ICC) taking as referent Byram's model (1997). Using the framework of qualitative action research, class activities, reflective journals and focus groups interviews were used to obtain the necessary information in order to reflect upon what students expressed regarding the ICC. The study revealed three categories: cultural recognition, cultural

1 This article is the result of scientific and technological research.

2 Holds a B.A. in Modern Languages: English and Spanish from Universidad Pedagógica y Tecnológica de Colombia (UPTC). He is a M.A. in Language Teaching candidate from the same university. He is a full-time English Teacher at Instituto Internacional de Idiomas at UPTC. His academic and research interests are focused on Language and Culture.
} 
experience and cultural reaction. Moreover, the results indicated that students were in an early stage of their ICC which was fostered through class activities. They understood the purpose and usefulness of the ICC. In addition, they were open and interested in including culture and ICC activities in the EFL classroom.

Key words: Language, Culture, Cultural Products, Cultural Practices and Intercultural Communicative Competence

\section{Resumen}

Este documento presenta los resultados de un estudio de investigación desarrollado con estudiantes de nivel básico de inglés del Instituto Internacional de Idiomas de la Universidad Pedagógica y Tecnológica de Colombia. A partir de un diagnóstico inicial, se diseñaron una serie de intervenciones pedagógicas las cuales buscaron explorar la Competencia Comunicativa Intercultural (CCI) de los estudiantes tomando como referente el modelo de (Byram, 1997). En el marco de una investigación-acción cualitativa, actividades en clase, reflexiones y entrevistas grupales fueron utilizadas para obtener la información necesaria para reflexionar sobre lo que los estudiantes expresaron en relación con la CCI. El estudio reveló tres categorías: Reconocimiento cultural, experiencia cultural y reacción cultural. Además, los resultados indicaron que los estudiantes estaban en una etapa temprana de su CCI la cual fue potenciada a través de actividades en clase. Ellos entendieron el propósito y la utilidad de la CCI. Adicionalmente, ellos estuvieron dispuestos e interesados en incluir la cultura y actividades de CCI como un componente importante en el salón de inglés como idioma extranjero.

Palabras clave: Idioma, Cultura, Productos culturales, Prácticas culturales, Competencia comunicativa intercultural.

\section{Introduction}

In the process of learning a language, linguistic information is replete with cultural features. The learner is sometimes unaware of these features which appear through body language, gestures, signs, clothing, food among other type of products and practices. The teacher, as a guide in the classroom, can give students the necessary tools in order for them to acquire or improve competences which they employ when using a language. There are different competences students can acquire or improve when learning a new language. The purpose of the article is to present information about the use of target language and cultural products and practices inside the classroom and their influence upon students' intercultural communicative competence (ICC). 
Interculturality and the inclusion of intercultural communicative competence are rarely if ever used in the Colombian EFL teaching environment. These practices are based upon grammatical and linguistic aspects and culture which are most often not seen as relevant to be learnt in classrooms. However, in the document 'Estándares Básicos de Competencias en Lenguas Extranjeras: inglés (2006), the cultural aspect is mentioned. The document's authors say that learning a foreign language leads students to respect their own culture and to develop respect for other cultures while encouraging them to value differences and plurality in their immediate surrounding as in the globalized world (p.8). But despite the fact that the government espouses the inclusion of culture in classrooms, some teachers continue teaching the grammatical elements only and in other cases they work focused on certain features of the communicative competence without creating a space for culture. Oftentimes, culture is considered a different element to be included inside the classroom working with food, music, clothing among other cultural products, but without going to the point of stating critical perspectives about the relationship between language and culture. In addition, due to government demands, institutions emphasize students' proficiency and accuracy in order to get good results on national examinations such as 'Saber 11' or 'Saber
Pro' and cultural features have little space to be developed.

Now, there is a vague concept about the significant relationship between language and culture (Klein, 2004). First, there is not a group of methodologies to teach culture inside the FL classroom (Wright, 1996), meaning that there is no a clear guide on how to work with culture and language inside the classroom and that teachers make the decisions about whether and how to include them. For Lafayette (1988) and Paige, Jorstad, Siaya, Klein and Colby (2000), textbooks do not deal appropriately with culture. The books are plain, and have a limited and biased view of culture. And even more, most of the books are strongly influenced by American or British cultures. According to Tomlinson (2011), these materials should be rich and varied in stimulating learning authentic interactions (p. 28).

In my particular case, the textbook which I work with is from a British publishing house. They did not make much effort to include culture. Few images, audios and activities represent the products, visages or practices of people from around the world. Most of these features represent the British and in some cases the American cultures. And even more, ICC activities are rarely available in this material. Regarding the previous statements, a research question emerged: What do students reveal about their intercultural communicative competence while they 
are involved in the use of a foreign culture products and practices?

\section{Defining Theoretical Constructs}

\section{Culture.}

Authors define culture in different ways. In first place it is possible to understand culture as communication (Hall, 1959). In this case people communicate through a lot of ways: verbal and non-verbal language, body language, time, space, social situations etc. Therefore, we can understand that to communicate with people goes beyond verbal language.

Another way to understand culture is through the 'Big C' and 'Small $c^{\prime}$ proposed by Halverson (1985). In this case the 'Big $C^{\prime}$ refers to art, architecture, literature and music. The 'Small c' is relevant as well because this makes reference to customs, traditions and everyday practices we engage in as humans. This view makes sense regarding more personal factors from people around the world.

Now, going deeper, Lusting and Koester defined culture as intercultural communication (1999). Here culture is the aptitude to access other cultures different from the own. Apart from the act of entering to another culture, intercultural communication requires one to communicate in this 'alien' culture appropriately and with effectiveness and to be able to use that target language to obtain what is needed or wanted.
Therefore, for the study I conducted, I defined culture as an enormous group of features represented in different fields and through different products and practices to communicate the essence of a particular group of people to itself and to others.

\section{Cultural Products.}

For Moran (2001) cultural products are the tangible part of a culture which its members have created. They are the main entrance to experience a new culture and can be seen, heard, smelled, taste and even felt. There are four categories to define cultural products: artifacts, places, institutions and art forms (p. 48).

Graphic 1. Cultural Products (Adapted from Moran, 2001)

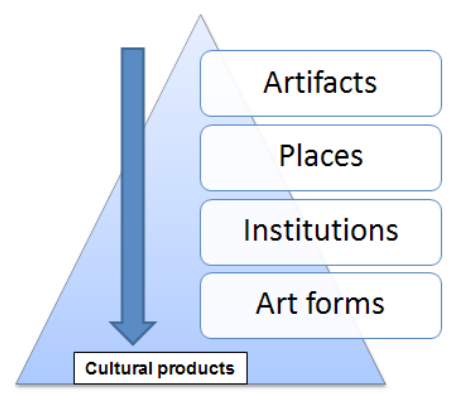

Artifacts refer to the things, the objects created, adapted or adopted by a culture. The list can be limitless: Books, cars, dishes, jewelry and movies just to mention a few of them. Most of these artifacts are specific to different cultures (Japanese kimonos or Colombian 'Vueltiaos' hats). Nowadays these artifacts are more common and 
accessible than in the past because of globalization. The places are the physical settings where people engage in their daily activities. They are the environments people have modified to their own needs and benefits. These places can be as small as a room in the house or as big as a public park or even a city or a country.

Institutions are the systems that regulate the practices of a culture's members. A school or a hospital is an institution where people perform specific practices with specific cultural products while sometimes using specific language or jargon. Finally, art forms are more complex products. They are the big $\mathrm{C}$ mentioned by Halverson (1985): architecture, literature, music and can be also cinema, clothing style, dance, decoration, design, painting and sculpture among others. They are understood from different points of view and cultural perspectives according to each person.

\section{Cultural Practices.}

Moran also talks about the cultural practices (2001). They constitute the actions the members of a culture do and make as their way of life, including language. They can be isolated (praying or cleaning the house) or interacting with other people (bargaining in a market or meeting with friends). They can be four types: operations, acts, scenarios and lives (p. 57).
Graphic 2. Cultural Practices (Adapted from Moran, 2001)

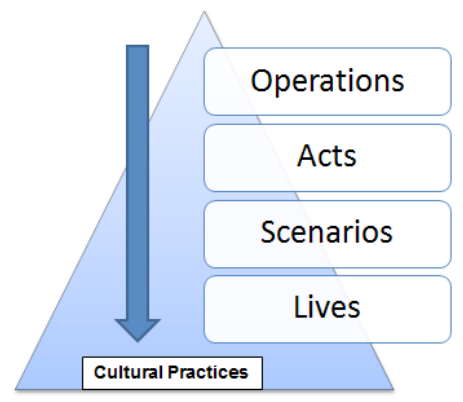

Operations have to do with using cultural products. In most cases they are solitary and language is infrequently used. Making a coffee or decorating a room can be examples of these operations. The acts are more systemized practices which include short communication. A greeting or asking for a price are representations of this cultural practice. Scenarios are the combination of operations and acts. They are more complex communicative practices. They can be as simple as making a phone call or presenting a job interview or more complicated such as buying a house or attending a baptism or be even more complex like attending to a language course or running a company. Finally, lives are people's cultural background that also includes language. They show how operations, acts and scenarios constitute those experiences people have navigated during their whole life. They are in constant change and it is possible to understand what they were like in the past and how they are now. 


\section{Language and Culture.}

Language is a product of the culture and therefore language is a window into culture (Moran, 2001). Hence, learning any foreign language skills leads to learning features of the language's cultural background. Moreover, culture is intrinsic to language learning and the teaching process. Sun (2013), views language as the main vehicle for beliefs, norms and values of a culture to be transmitted and consequently culture is learnt in explicit and implicit ways at the same time. For Dai, Z. (in Mahmoud, 2015), language learning and culture are linked to each other. This relationship is evidenced inside and outside the classroom not only with language use for specific purposes (greeting or asking for directions) but the use of language in everyday life (p. 68). According to Hesar, Konca and Zarfsaz (2012):

In language learning, culture is significantly important and is an item that cannot be disregarded because, culture acts as if the flesh and language as the skeleton of a society. If there is no culture, there is no language. Therefore, a language class cannot be imagined without involving the cultural elements of the targeted language (p. 69).

Hence, if culture is excluded from the language learning process, students will have a gap between the means to communicate and how they actually communicate because of the low development or lack of intercultural competence.

Finally, Abdollahi-Guilani, Yasin, Hua, and Aghaei (2012) express that learners can learn about history, geography, customs, life styles and other features where the target language is spoken. This offers students the possibility of becoming closer and more familiar with the target culture and language. Thus the relationship between language and culture is inherent and one cannot be used separately from the other, otherwise it would be an artificial practice.

\section{Intercultural Communicative Competence.}

Byram (1997) states that the intercultural communicative competence concept takes into account how people should know, interpret, relate, and interact with other cultures when learning and using foreign languages. He proposes a set of 5 dimensions inside his intercultural communicative competence approach. These dimensions or saviors are the basis of the knowledge and use of a language. The saviors are the following: Savoir (knowledge); Savoir être (know to be); Savoir comprendre (know to comprehend); Savoir apprendre (know to learn) and Savoir s'engager (know to be aware).

The first 'Savoir' is related to the knowledge of the self, the other and the awareness of the relationship between the individual and society. 
Savoir être are attitudes in intercultural terms or in other words to be open to the other with curiosity and have the ability to understand the unfamiliar with creativity and imagination while valuing others' attitudes and beliefs. The third one, Savoir comprendre, refers to understanding issues from another culture while making comparisons to one's own culture and developing different perspectives thanks to comparisons and contrasts. Savoir apprendre, the fourth dimension, relates to discovery and interaction through the exploration of one's own and other's cultures. Finally, the fifth savoir Savoir s'engager, deals with the development of critical cultural awareness and the issue of analyzing political education.

\section{Methodology}

As the idea was to provide the students with a place to reflect about their intercultural communicative competence, it was decided to use the action research approach (Kemmis and Mctaggart, 1988) following these steps: observe, plan, act and evaluate. Burns (2010) mentions this approach with a focus on the language teaching process. She broadens the notion of action research in language teaching by describing this kind of study as group of activities related to curriculum and professional development and school and educational policies improvement. According to her adaptation, research might be restructured, as needed, during the development of the project.
In addition, Burns places emphasis on the participants who are considered the main participants in the process.

Bearing in mind the two previous definitions, I developed my plan of action following a systematic series of steps. First of all, I decided to choose a research field which is important to me and my work context. After the initial reflection, I narrowed the topic looking to have an impact on my work environment. I designed and applied a series of pedagogical interventions in which each intervention had a specific purpose in the study. During the pedagogical interventions a group of techniques and instruments which helped to gather the necessary information for the study were employed. At this stage I started my preliminary analysis using the data gathered and after each intervention I took the opportunity to modify the upcoming interventions' relevant elements making them more effective and accurate so as to fulfill the main objective of the research. This provided me with the opportunity to use an approach which was useful in my context. After the implementation of the class activities, I reflected upon the outcome of applying the pedagogical interventions and then I categorized my findings. Finally, I wrote this document to communicate what English teachers are doing in educational research in this context. The following graphic presents the way I approached the action research process. 
Graphic 3. Action Research Process (Adapted from: Kemmis, S., and McTaggart, R,.1988; Burns A., 2010).

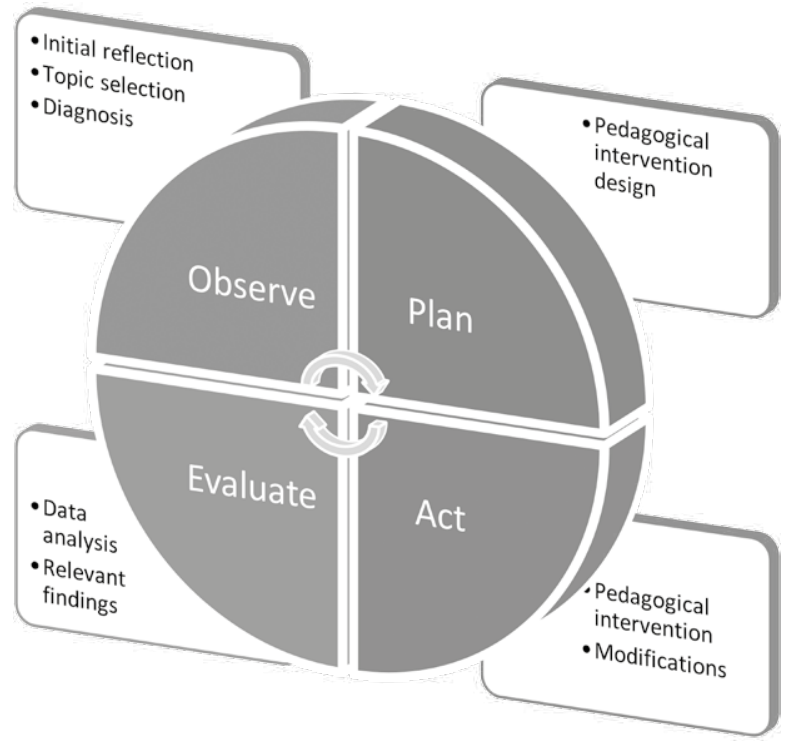

\section{Research Setting}

\section{Context.}

Universidad Pedagógica y Tecnológica de Colombia is a public university located in Tunja, the capital city of the department of Boyacá, Colombia. It is the most important city in this region of the country. The university offers majors in law, medicine, engineering, economics and varies teaching degrees among others which total thirty undergraduate programs. These students have to take four levels of a foreign language as one their major's requirements. These levels range from elementary to intermediate according to the Common European Framework of Reference for Languages: learning, teaching, assessment, (CEFR). Each level is equal to sixty-four work hours completed during an academic semester and the students attend two hour sessions every week. These sessions are offered by the Instituto Internacional de Idiomas which is an office of the same University. Students choose to learn English, French and German. They take a placement test in order to be assigned to the levels according to their languages knowledge. Besides, they can take a standardized exam which frees them from coursing the four levels and declare they have accomplished this degree requirement.

\section{Participants.}

The participants were elementary English level students who belong to different semesters and university academic programs (BA in Mathematics 
teaching, Business Administration, Environmental Engineering, Metallurgical Engineering, Psychoeducation, and Psychology). Their ages range from 17 to 28 years old. The sample was composed of 8 students. During a spontaneous talk in class, I invited students to take part of the study. I explained the purpose and study's methodology to them and 8 students accepted the invitation to participate voluntarily. All 8 of the participants signed the consent form so that I had ethical and legal support for the research I was doing.

The participants were identified using a number with the intention to keep their identities private thus giving them more confidence when participating in the study's activities. They were identified as Student 1 , Student 2, Student 3, up to Student 8 . The sample was not forced, meaning the students participated freely and thus ensuring reliable data.

\section{Instruments.}

In order to guarantee the validity and reliability of this study and to triangulate the information gathered, surveys, reflective journals and focus group interviews were used. The surveys helped in obtaining information about the participants' background as well as their prior knowledge and opinions about language and culture and the intercultural communicative competence (See annex 1).
The journal was used as a tool to record students' perceptions and advances through the pedagogical interventions. For Ortlipp (2008), using reflective journals enables the researcher to make experiences, opinions, thoughts, and feelings visible and an acknowledged part of the research design, data generation, analysis, and interpretation process (p. 703). The students' reflections were recorded in reflective journal entries.

The focus groups interviews were a more in depth way to look for specific information not encountered through the use of the two previous techniques. For Janesick (1998), interviews allow for communication to be established, thus relevant meanings about a theme can be built. Krueger (1997) states that focus group interviews are used to collect peoples' opinions about a product, service idea or theme. These interviews function well because the participants feel relaxed, appreciated and free to participate by expressing their insights about a topic without the fear of being judged. The initial survey, the reflective journals and the focus groups interviews were the fundamental basis for triangulating, analyzing and interpreting the information gathered.

\section{Pedagogical Intervention.}

The pedagogical interventions were implemented during six sessions which occurred every other week during a nearly three and half month period of time. I developed the pedagogical 
interventions with the whole group and because of the ethical considerations I asked for their voluntary participation. The interventions were developed in a defined period of time at the beginning or the end of the classes depending on the objectives and activity's contents. They were allowed to express their ideas in the foreign language they were learning, English, and in some cases their native one, Spanish.

At the beginning of the study, a diagnosis was done regarding students' background and Byram's (1997) intercultural communicative competence 'saviors'. The students' competences were recorded through an adapted rubric based on the Byram's ICC model (See annex 1). During this stage, they were asked about their conceptions about the relation between language and culture. The rubric asked for the abilities attitudes and knowledge needed to deal with a foreign culture, practices and products. After analyzing the rubric results, a series of workshops and class activities were designed to inquire about the students' perceptions regarding the intercultural communicative competence model.

The objectives of the workshops were first to raise students' awareness about culture. Secondly, to experience the culture through real contact with native speakers of the target language. And third, to show how the students' perceptions emerged regarding intercultural communicative competence.

\section{First Stage: Becoming culturally aware.}

In the first workshop students used local and foreign newspapers as cultural products in order to find cultural similarities and differences between the two products with the intention to foster students' conception of local and foreign cultures through the comparison. Then they wrote a reflective journal entry to record their experiences. In order to reinforce this first objective, during the second activity students watched two movies trailers; one from a Colombian movie and another from the target foreign culture. Again, the idea was to contrast two cultural products and try to find elements that were similar or different which facilitated student expression of their notions of culture (See annex 2 ). The stage was concluded with the students writing a second journal entry.

\section{Second Stage: From culturally aware to interculturally competent.}

Now, bearing in mind students had an initial experience, two other activities were developed. The third and the fourth interventions offered students the opportunity to experiment with culture through communication with target language native speakers. In the third one the participants had a conversation with an English native speaker. During this time, the group and the foreigner exchanged questions and answers about different topics: education, politics, religion, language, 
customs, and traditions among others. They used the Language 1 and Language 2 during this exercise. Afterward, they recorded their reflections in another journal entry.

With the purpose of supporting this first contact, in the fourth intervention students were asked to have contact with students from foreign cultures and languages. They told and read a childhood anecdote. Based on their anecdotes and their classmates' ones, they reflected and wrote their fourth entry. The communication, exchange of information and expression of thoughts and feelings were the means for the students to put into practice the intercultural communicative competence.

\section{Third Stage: On the road to} become interculturally competent.

Finally, students developed one closing activity in which they participated in a group discussion led by the teacher. A set of questions were asked and students contributed to the conversation. The goal of the chat was to listen to the participants sharing ideas about their perception of the relationship between language and culture and the intercultural communicative competence.

\section{Findings}

Based on an initial survey and a rubric students reflected since the beginning of the project. In the rubric, based on Byram's model, they expressed that the relation between language and culture is important. Concepts such as customs, ideologies, values, religion, communication, education, mistakes, knowledge exchange, identi-ties, and diversity were fundamental to understanding a foreign culture. For instance student $\mathbf{1}$ said: "The language and the culture closely related concepts as language is a historical cultural construction as through the traditions, customs that allow us to learn and understand our environment" (Survey excerpt). In the same sense student 2 declared "They go hand in hand because learn new languages help to know more people in other countries, know different custom and learn of these" (Survey excerpt). At this stage they mentioned the concepts but they did not give more information to explore about their intercultural communicative competence. Hence, this was the starting point to design and implement the workshops. Then, the following categories emerged as shown in the following figure. Figure No. 1 shows the relationship between the objectives proposed and the categories found and graphic No. 4 illustrates the progression of the emerging categories. 
Figure 1. Data analysis relation

\begin{tabular}{|c|c|}
\hline \multicolumn{2}{|c|}{ Research question } \\
\hline \multicolumn{2}{|c|}{$\begin{array}{l}\text { What do students reveal about their intercultural communicative competence while they are } \\
\text { involved in the use of a foreign culture products and practices? }\end{array}$} \\
\hline Objectives & Categories \\
\hline $\begin{array}{l}\text { To determine to what extent students are } \\
\text { aware of their own and foreign cultures } \\
\text { using cultural products and practices }\end{array}$ & Cultural recognition \\
\hline $\begin{array}{l}\text { To analyze students' perceptions about a } \\
\text { foreign culture in front of their own one. }\end{array}$ & Cultural experience \\
\hline $\begin{array}{l}\text { To evidence students progression } \\
\text { regarding their intercultural } \\
\text { communicative competence after the } \\
\text { pedagogical interventions }\end{array}$ & Cultural reaction \\
\hline
\end{tabular}

Graphic 4. Categories progression

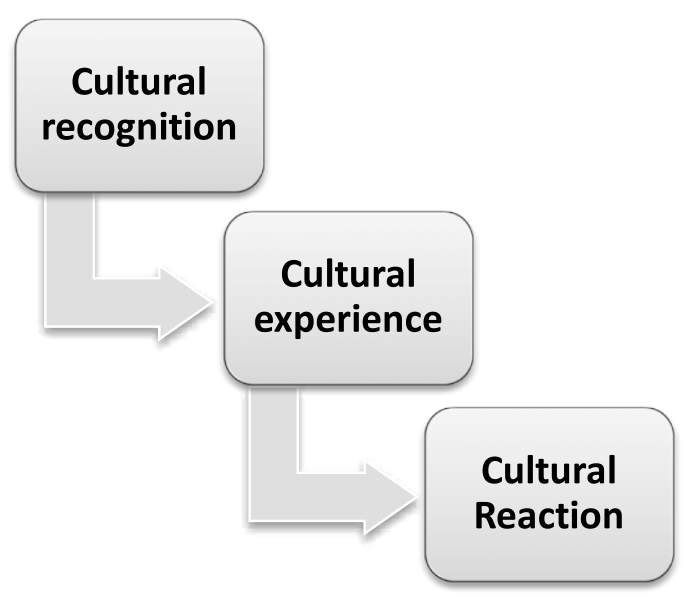

\section{First category: Cultural}

\section{recognition.}

In the first activity they used local and foreign newspapers as cultural products in order to find cultural similarities and differences between the two products. During this first workshop, students focused on the materials layout and they paid attention to elements such as font, color and even price. Student 3 said:

...los periódicos tienen una diferencia en la fuente que manejan, organización de los párrafos, los tipos de imágenes... los colores que manejan, ejemplo el periódico el tiempo que por cierto es de Colombia maneja un tipo 
de color más encendido y llamativo. El otro New York times el tipo de colores que maneja es más serio...' (Reflective entry extract). [Newspapers have a difference in the sourced they manage, paragraph organization, type of images... colors. For example, the newspaper El Tiempo that is a Colombian newspaper where they use striking colors. The other one is the New York times where the color is more discreet...]

They also expressed that the newspapers deal with politics or religion issues but not in depth. Here they manipulated the cultural products and were engaged in analyzing and comparing them.

Taking into consideration that students did not interpret differences between cultures, the second workshop was implemented. Participants were asked to bear in mind beliefs, customs and values they could identify. During this second activity they worked with audio visual materials including two movie trailers which were used as cultural products. The idea was to ask the students about the cultural products and explicit and implicit practices in the local and foreign trailers. Comparisons appeared and they started to notice some differences. Student 4 expressed 'En estados unidos los jóvenes tienen muchos problemas en preparatoria' [In the United States Young people have lots of problems at high school] (Reflective entry extract). In this case, it was evidenced that students used the first dimension stated by Byram, the savoir. They were aware of other social groups with products and practices. On the other hand, Student 5 said:

...en la situación colombiana el superhéroe es más caritativo... mientras el de EE.UU. se basa en desenmascarar a los delincuentes. ...uno es más caritativo y el otro se encarga de combatir con los delincuentes... mientras que el colombiano es con la fe del Divino Niño' (Reflective entry extract). [...In the Colombian situation the superhero, is the most charitable... while in EE.UU is based on unmask to offenders.... one of them is charitable and the other one is in charge of fight against the offenders... while the Colombian has faith in the Divino Niño]

Again the students were aware of the social practices but at this stage the student went beyond giving an illustration of a cultural practice, which in this case was faith in a religious figure.

Student 6 stated:

...los contextos en los que se desenvuelven son supremamente diferentes. En el escenario están implícitas creencias tales como las creencias religiosas y costumbres como tomar tinto. ...no es lo mismo terminar envuelto en guerras de drogas, donde se maneja mucho dinero, que cuando se lucha con pocos recursos en búsqueda de una igualdad social' (Reflective entry extract). [... "the contexts where they are extremely different. In the setting, there are beliefs that are implicit, such as beliefs related to religion, customs like drink a coffee.... It is not the same to be immersed in wars and drugs, where people have money, when one fights with poor resources in order to look for social equality" ] 
This demonstrates the savoir comprendre stated by Byram in which this student is making a comparison and relationship between two events. Therefore, this first category makes reference to how students started to focus on their own culture as well as the other.

\section{Second Category: Cultural experience}

Thanks to the development of the third and fourth activities, students started to state positions about the language and culture. For instance, student 6 stated:

Let's continue with the language, this is the most visible difference between the two countries, while in Barbados the people speak English in Colombia, we speak Spanish. In Barbados the language was imposed by the United Kingdom and in Colombia was imposed by Spain. In both of them countries, exist accents in the language (Reflective entry extract).

In the same sense, Student 7 said: ...those were colonized for European king ... arrived to impose this culture occidental' (Reflective entry extract). According to Abdollahi-Guilani et al. (2012), in this case students learned target language features. Moreover, the students emphasized the imposition of a language and customs in both countries.

Student 7 also declared: The principal sport in Barbados is the Criquet (British influence) and the national sport of our country is the Tejo (Ancestral indigenous game) (Reflective entry extract). Here the student referred to the savoir s'engager or two different cultural practices developed in different contexts. He expressed the knowledge of two different sports practiced in the two countries emphasizing their imposed and traditional origins. The Student 5 added: In the chat with the assistant I knew a lot of things about Barbados... is a little country, doesn't matter the distance from UK they still keeping some aspects of their culture because of they were colonized by UK (Reflective entry extract). Again students reinforced the idea of colonization. This second category showed the students insights when interacting with people from other cultures.

\section{Third Category: Cultural reaction}

Students stated positions about the intercultural communicative competence. They talked about it using their own definition. Student 3 declared: The intercultural communicative competence is at the same time the set of skill the culturally different individuals use to favor effective communication, establishing appropriate and effective behaviors in certain social and cultural context (Interview passage). Here there is evidence that students understood the ICC as a tool to communicate to others. In this sense Student 2 expressed ... ICC is that competition that people have to learn a second language and thereby be able to function on other different 
culture to which it belongs, by doings this could know the different customs that have each (Interview passage). So they had an initial idea about the purpose of boosting their ICC.

In addition, they expressed, in their own words, the purpose of the ICC. For instance, Student 3 said:

The intention of an intercultural communicative competence is to know, to learn, to interact, to exchange customs, explore on other cultures as his traditions, myths, legends, gastronomy and his grammar as a way of improving the lexicon, investigating and generating a series of tools to guarantee the mobility, interaction, access to other cultures, integration and understanding of them (Interview passage).

In this part, the student expanded the scope of the ICC including cultural products and practices to become a conscious person when dealing with a foreign culture. Student $\mathbf{8}$ added Intended to be cross-culturally competent is able to relate to different people, to learn about their customs, language, history and the different activities carried out, to be part of different communities... (Interview passage). These are two samples of how students started to focus on the use, purpose and importance of the ICC. Finally, this last category defines the students' position about the relationship between language and culture with the use of the intercultural communicative competence.

\section{Conclusions and Implications}

After the implementation of this research, I noticed some benefits and limitations which appeared during the pedagogical interventions. Regarding the benefits, it was evident students were engaged while participating in the different activities. Clearly they wanted to express their ideas about the relationship between language and culture and the importance of using the intercultural communicative competence in their foreign language learning and use. Students showed will and motivation to take part in the workshops. As a teacher, I felt motivated to develop these kinds of activities and foster students' participation and ICC development.

On the other hand, some limitations also became clear during the course of the work on the study. First of all, students' foreign language level was an obstacle for them to express ideas. As they are in an elementary level they have only a basic vocabulary background and for this reason, in some cases, they used their native tongue. Because the course did not have spaces to deal with language and culture, sometimes the activities were conducted in short periods of time. Finally, I came to some research outcomes related to attitudes, skills, knowledge and language students demonstrated regarding their intercultural communicative competence. 
Figure 2. Research outcomes

\begin{tabular}{|c|c|c|c|}
\hline Attitudes & Knowledge & Skills & Language \\
\hline $\begin{array}{l}\text { The students } \\
\text { were willing } \\
\text { and eager to } \\
\text { learn about other } \\
\text { cultures and } \\
\text { their features. } \\
\text { They were ready } \\
\text { to experience } \\
\text { culture from a } \\
\text { different point of } \\
\text { view. }\end{array}$ & $\begin{array}{l}\text { They understood } \\
\text { there is no one } \\
\text { unique culture. } \\
\text { They kept in mind } \\
\text { that there are other } \\
\text { cultures which have } \\
\text { their own cultural } \\
\text { products and } \\
\text { practices as well as } \\
\text { theirs. Moreover, } \\
\text { they looked at their } \\
\text { own culture from a } \\
\text { new perspective. }\end{array}$ & $\begin{array}{l}\text { They learnt } \\
\text { the abilities of } \\
\text { identifying, } \\
\text { understanding } \\
\text { and interpreting } \\
\text { own and foreign } \\
\text { cultural products } \\
\text { and practices. } \\
\text { Besides, the students } \\
\text { evaluated with their } \\
\text { own perception their } \\
\text { own and foreign } \\
\text { cultural products and } \\
\text { practices. }\end{array}$ & $\begin{array}{l}\text { The students used } \\
\text { the foreign language } \\
\text { to express their } \\
\text { thoughts about the } \\
\text { ICC and their own } \\
\text { and foreign cultural } \\
\text { products and } \\
\text { practices. }\end{array}$ \\
\hline
\end{tabular}

To conclude, I can say that at this stage the students began to raise awareness about the cultural differences. They started to show interest in the Intercultural Communicative Competence because they participated, asked questions about cultural features, made comparisons between cultures and stated critical points of views regarding their culture and other cultures. Also, the way they learned to use EFL not only inside the classroom, but outside in real communicative situations made clear that it is appropriate to continue fostering their ICC not only with isolated interventions but as a part of the curriculum.

\section{References}

Abdollahi-Guilani, M., Yasin, M. S. M., Hua, T. K., and Aghaei, K. (2012).
Culture-Integrated Teaching for the Enhancement of EFL Learner Tolerance. Asian Social Science, 8 (6),115.

Burns, A. (2010). Doing action research in English language teaching: A guide for practitioners. New York: Routledge.

Byram, M. (1997). Teaching and assessing intercultural communicative competence. Clevedon: Multilingual Matters.

Byram, M., Gribkova, B., and Starkey, H. (2002). Developing the intercultural dimension in language teaching. Strasbourg: Council of Europe, 41.

Common European framework of reference for languages: Learning, teaching, assessment. (2002). Strasbourg: Council of Europe Publ.

Hall, E. T. (1959). The silent language (Vol. 3, p. 1959). New York: Doubleday.

Halverson, R. J. (1985). Culture and vocabulary acquisition: A proposal. Foreign Language Annals, 18 (4), 327-332. 
Hesar, M., Konca, M., and Zarfsaz, E. (2012). Why and how to apply culture in an EFL classroom. In 2012 International conference on language, medias and culture proceedings (Vol. 33, pp. 68-72).

Janesick, V. J. (1998). "Stretching" exercises for qualitative researchers. Thousand Oaks, CA: Sage.

Kemmis, S., and McTaggart, R. (1988). The action research planner. Geelong, Victoria: Deakin University Press.

Klein, F. (2004). Culture in the foreign language classroom: Teachers' beliefs, opportunities and practice. (Doctoral dissertation, University of Minnesota). Dissertation Abstracts International, A: The Humanities and Social Sciences, 64 (4), Oct, 1235-A, 319.

Krueger, R. A. (1997). Moderating focus groups. Thousand Oaks: Sage

Lafayette, R. C. (1988). Integrating the teaching of culture into the foreign language classroom. In A. J. Singerman (Ed.), Towards a new integration of language and culture (pp. 47-62). Northeast Conference on the Teaching of Foreign Language. Middlebury, VT: Northeast Conference.

Lusting, M., Koester J. (1999). Intercultural competence: Interpersonal communication across cultures. NY: Addison-Wesley Longman.

Mahmoud, M. A. (2015). Culture and English Language Teaching in the Arab World. Adult Learning, 26(2), 66-72.

Ministerio de Educación Nacional. (2006) Estándares Básicos de Competencias en Lenguas Extranjeras: Inglés. Formar en lenguas extranjeras: Inglés jel reto!. Bogotá: IPSA

Moran, P. R., and Lu, Z. (2001). Teaching culture: Perspectives in practice. Boston, MA: Heinle and Heinle.

Ortlipp, M. (2008). Keeping and using reflective journals in the qualitative research process. The qualitative report, 13 (4), 695-705.

Paige, R. M., Jorstad, H. L., Siaya, L., Klein, F., and Colby, J. (2000). Culture learning in language education: A review of the literature. St Paul, MN: Center for Advanced Research on Language Acquisition, The University of Minnesota.

Sun, L. (2013). Culture Teaching in Foreign Language Teaching. Theory and Practice in Language Studies, 3 (2), 371-375.

Tomlinson, B. (2011). Materials development in language teaching. Cambridge University Press.

Wright, M. (1996). The cultural aims of modern language teaching: Why are they not being met? Language Learning Journal 13, 36-37. 


\section{ANNEX I \\ Universidad Pedagógica y Tecnológica de Colombia \\ Vicerrectoría Académica \\ Instituto Internacional de Idiomas \\ Idioma Extranjero II \\ Survey}

Dear student, please answer the following questions, based on your own experience, in order to know your perception about the relationship between Language and Culture. The purpose of this survey is to gather valuable information for a research project. Be honest with your answers.

Name: (Optional) Date:

\section{Background Information}

Please mark the option(s) or answer(s) what applies to you:

1. What is your age?

2. What is your gender? Male Female

3. Where are you from?

4. What academic program do you belong to?

5. What semester are you in?

6. Years learning and / or studying a foreign language:
$0-1$
$1-2-2-3$
$3-4$
$4-5$
More

than 5

\section{Language and Culture}

1. What do you understand about the relationship between Language and Culture?

III. Intercultural competence self-assessment (Adapted from Byram, 2002)

\begin{tabular}{|l|l|l|l|}
\hline STAMENT & YES & NO & If yes, how? If no, why? \\
\hline $\begin{array}{l}\text { I am aware of the existence of } \\
\text { social groups in my culture which } \\
\text { have their own perspectives, } \\
\text { practices and products as well as } \\
\text { other cultures with social groups } \\
\text { which have their own perspectives, } \\
\text { practices and products }\end{array}$ & & & \\
\hline
\end{tabular}




\begin{tabular}{|c|c|c|c|}
\hline STAMENT & YES & $\mathrm{NO}$ & If yes, how? If no, why? \\
\hline $\begin{array}{l}\text { I am open and ready to recognize } \\
\text { beliefs, customs and values about } \\
\text { other cultures and about my own } \\
\text { ones }\end{array}$ & & & \\
\hline $\begin{array}{l}\text { I have the ability to interpret an } \\
\text { event and / or document from } \\
\text { another culture and comparing it } \\
\text { to events and / or documents from } \\
\text { my own culture }\end{array}$ & & & \\
\hline $\begin{array}{l}\text { I have the ability to acquire } \\
\text { new knowledge and cultural } \\
\text { practices from another culture. } \\
\text { And the ability to use this } \\
\text { knowledge, attitudes and skills in } \\
\text { communication }\end{array}$ & & & \\
\hline $\begin{array}{l}\text { I have the ability to evaluate, } \\
\text { critically and on the basis of explicit } \\
\text { criteria, perspectives, practices and } \\
\text { products from other countries and } \\
\text { cultures and my one's own }\end{array}$ & & & \\
\hline
\end{tabular}

Thank you! 


\section{ANNEX II}

\section{Universidad Pedagógica y Tecnológica de Colombia \\ Vicerrectoría Académica \\ Instituto Internacional de Idiomas \\ Idioma Extranjero II \\ Superhero}

\section{Objective}

To raise cultural awareness regarding differences with the use of authentic foreign and local cultural products

I. Think about a superhero. How do you imagine her / him? What characteristics, powers, and weaknesses does s/he have? Where does s/he live? Who does s/he help?

II. Pay attention to the movies trailers and fill in the charts. Write down aspects related to the different features that call your attention.

\begin{tabular}{|l|l|l|l|}
\hline \multicolumn{2}{|c|}{ 'El Man' } & \multicolumn{2}{c|}{ 'Kick ass' } \\
\hline FEATURE & DESCRIPTION & FEATURE & DESCRIPTION \\
\hline $\begin{array}{l}\text { People: physical } \\
\text { appearance, clothing }\end{array}$ & & $\begin{array}{l}\text { People: physical } \\
\text { appearance, clothing }\end{array}$ & \\
\hline Places & & Places & \\
\hline Food / Drink & & Food / Drink & \\
\hline Situations & & Situations & \\
\hline
\end{tabular}

III. Write a reflective entry in which you express your thoughts about the videos. Take into account the message and the aspects you liked or disliked about them. Bear in mind the following questions:

1. What cultural products are explicit and or implicit in the scenarios?

2. What cultural practices are explicit and or implicit in the scenarios?

3. How do these products and practices contrast? 